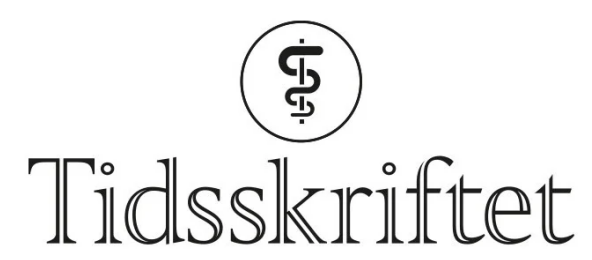

DEN NORSKE LEGEFORENING

\title{
Evnen til å uttrykke seg
}

FRA REDAKTØREN

PETTER GJERSVIK

petter.gjersvik@medisin.uio.no

Petter Gjersvik er medisinsk redaktør i Tidsskriftet. Han er professor ved Institutt for klinisk medisin, Universitetet i Oslo, der han underviser om hudsykdommer og leder en eksamenskommisjon i flere fag.

\section{Medisinstudiet legger for liten vekt på å styrke studentenes evne til å formulere seg.}

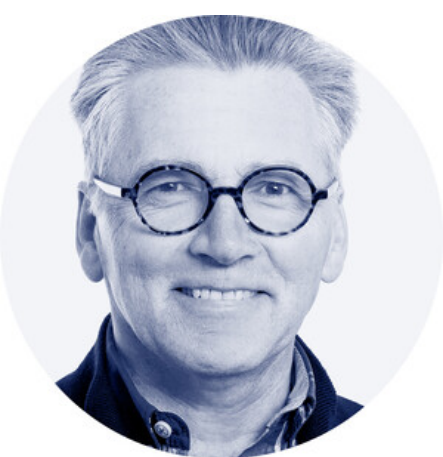

Foto: Sturlason

Språk er nært knyttet til tenkning og kognitive prosesser. Vi trenger ord for å forstå og formidle vår oppfatning av virkeligheten. Leger i alle spesialiteter bruker tale og skrift for å kommunisere med hverandre, med sine pasienter og med samfunnet. Derfor er legers evne til å forstå og å gjøre seg forstått like viktig som kunnskap og praktiske ferdigheter.

Kommunikasjon og språk er i kjernen av hva alle leger, også klinikere, driver på med. Et klart, forståelig og tilstrekkelig presist språk er imidlertid ikke enkelt. Det krever både erfaring, ferdigheter og holdninger (1).

God kommunikasjon er alltid toveis. Form og innhold må tilpasses situasjon og mottaker og justeres når det trengs. Dette gjelder ikke minst i legers kommunikasjon med pasienter. Vi vet at svikt i kommunikasjonen mellom lege og pasient er en hyppig årsak til feil og klagesaker i helsetjenesten (ㅁ). Presis informasjon i en henvisning er viktig for å kunne gjøre riktige vurderinger og prioriteringer i spesialisthelsetjenesten (3), og dårlig språk kan gi legeerklæringer mindre tyngde (4). Slurvete henvisninger og uforståelige epikriser kan gjøre pasientbehandlingen dårligere og helsevesenet mindre effektivt. 
Medisinsk fagspråk står sentralt i all medisinsk utdanning. Studentene skal lære mange nye ord og faguttrykk og lære å observere, notere, vurdere og formidle. Derfor må studiet inneholde læringsaktiviteter som bidrar til å utvikle studentenes evne til å uttrykke seg muntlig og skriftlig. Tiden for slike læringsaktiviteter i medisinstudiet er imidlertid begrenset. Desto viktigere er det at alle mulighetene for tilbakemeldinger fra lærer til student utnyttes på en god måte. Dessverre er mangelfull tilbakemelding fra lærerne på journalskriving og muntlige fremleggelser av kliniske funn ved pasientundersøkelser en gjenganger ved studentenes evalueringer av studiet. Noen studenter gjennomfører studiet med minimal tilbakemelding på sine muntlige og skriftlige redegjørelser.

\section{"Legers evne til å forstå og å gjøre seg forstått er like viktig som kunnskap og praktiske ferdigheter»}

Medisinsk fagspråk er like viktig for leger som juridisk fagspråk er for jurister. Begge deler kan være vanskelig å forstå for mange. Det juridiske fakultet i Oslo har iverksatt flere tiltak for å gi jusstudentene mer skrivetrening (5). Der kan våre medisinske fakulteter finne inspirasjon og ideer til å bedre sin undervisning.

Studenters studieatferd og prioriteringer påvirkes av mange faktorer, bl.a. eksamen. I $\emptyset$ kende grad gjennomføres nå eksamen på medisinstudiet digitalt med avkrysningsoppgaver (multiple choice questions, MCQ). Dette er oppgaver der studentene skal svare ved å krysse av for «det mest riktige» av 3-4 forhåndsdefinerte svaralternativer ( $\underline{6}$ ). Noen studenter vil kunne identifisere riktig svaralternativ ved å gjenkjenne sentrale ord $\mathrm{i}$ svaret (7.), og mange lærer seg metoder for å eliminere gale svaralternativer (ㅁ). Evnen til å svare uten hjelpemidler og med egne formuleringer, slik leger må i de fleste situasjoner i yrkeslivet, blir ikke testet. Enda verre er at studenter kan legge seg til en farlig vane i klinisk praksis: De velger bort resonnement og refleksjon, som tar tid og krever en innsats, og gjetter når de ikke vet hva som bør gjøres. Evnen til å beskrive kliniske funn, for eksempel et brokk, et utslett eller et røntgenbilde, og å gjennomføre et fornuftig resonnement er viktigere enn evnen til å krysse av på et skjema.

Dagens medisinstudenter har svært gode karakterer fra videregående skole eller har brukt år på å forbedre sine karakterer i enkeltfag (9.). Studentene er derfor godt motiverte og kvalifiserte til å ta fatt på et krevende studium. Likevel er studentmassen ikke så homogen som mange synes å tro. Evner og forutsetninger varierer mye, og evnen til å uttrykke seg er ikke alltid så god som man kunne forvente. Dette gjelder studenter både med og uten innvandrerbakgrunn. En 5-er eller 6-er i norsk fra videregående skole er ingen garanti for at studenten skriver godt. Læreplaner, undervisning og eksamensformer i medisinstudiet må derfor være slik at studentenes evne til å uttrykke seg dyrkes, fremmes og utvikles.

\section{LITTERATUR}

1. Tønnesson JL. Ti teser om klart språk. Michael 2021; 18 (Suppl 26): 212-21.

2. Thorsen $\mathrm{O}$, Hartveit M, Baerheim A. The consultants' role in the referring process with general practitioners: partners or adjudicators? a qualitative study. BMC Fam Pract 2013; 14: 153. [PubMed] [CrossRef]

3. Aarseth G, Lie AH, Natvig B. Hvordan står det til med legeerklæringene? Tidsskr Nor Legeforen 2012; 132: 2148-9. [PubMed][CrossRef]

4. Gallagher TH, Mazor KM. Taking complaints seriously: using the patient safety lens. BMJ Qual Saf 2015; 24:352-5. [PubMed][CrossRef]

5. Nordrum JCF. Arbeidet med juridisk klarspråk. Michael 2021;18 (Suppl 26): 201-11.

6. Gjersvik P. Eksamenslære for dummies. Tidsskr Nor Legeforen 2020; 140. doi:

10.4045/tidsskr.20.0142. [PubMed][CrossRef] 
7. Sam AH, Westacott R, Gurnell M et al. Comparing single-best-answer and very-short-answer questions for the assessment of applied medical knowledge in 20 UK medical schools: Cross-sectional study. BMJ Open 2019; 9: e032550. [PubMed][CrossRef]

8. Wessel J. Eksamenseksperter med svake kunnskaper. Tidsskr Nor Legeforen 2021; 141. doi: 10.4045/tidsskr.20.0946. [PubMed][CrossRef]

9. Studieplasser i medisin i Norge. Behov, modeller og muligheter. Oslo: Kunnskapsdepartementet, 2019.

https://www.regjeringen.no/contentassets/9b5b81d102384507b8515of2eof1bo89/117459oo_rapport_utr edning_fra_grimstadutvalget.pdf Lest 4.10.2021

Publisert: 8. november 2021. Tidsskr Nor Legeforen. DOI:10.4045/tidsskr.21.0747

(C) Tidsskrift for Den norske legeforening 2023. Lastet ned fra tidsskriftet.no 26. april 2023. 